\title{
Comparative examination of pollutant emission from an automotive internal combustion engine with the use of vehicle driving tests
}

\begin{abstract}
The pollutant emission from automotive internal combustion (IC) engines is highly susceptible to engine operation states determined by vehicle velocity processes. The article presents results of comparative examinations of specific distance pollutant emission characteristics determined from various vehicle driving tests. The specific distance pollutant emission was determined using vehicle type-approval and special tests as well as tests developed at the Automotive Industry Institute (PIMOT), treated as realizations of the stochastic process of vehicle velocity. The research results confirmed high susceptibility of the IC engine pollutant emission to the engine operation states, which endorses the usefulness of treating the conditions of operation of automotive engines as stochastic processes.
\end{abstract}

Key words: internal combustion engines, pollutant emission, vehicle driving tests, stochastic processes

\section{Badania porównawcze emisji zanieczyszczeń z samochodowego silnika spalinowego z zastosowaniem testów jezdnych}

\begin{abstract}
Emisja zanieczyszczeń z samochodowych silników spalinowych jest bardzo wrażliwa na stany pracy silników zdeterminowane procesami prędkości samochodów. Wniniejszej pracy przedstawiono wyniki badań porównawczych charakterystyk emisji drogowej zanieczyszczeń w różnych testach jezdnych. Do wyznaczania emisji drogowej zanieczyszczeń wykorzystano testy stosowane w procedurach homologacyjnych i testy specjalne oraz opracowane w Przemystowym Instytucie Motoryzacji, traktowane jako realizacje procesu stochastycznego prędkości samochodu. Wyniki badań potwierdzity znaczna wrażliwość emisji zanieczyszczeń na stany pracy silnika spalinowego, co potwierdza celowość traktowania warunków pracy silników samochodowych jako procesów stochastycznych.
\end{abstract}

Słowa kluczowe: silniki spalinowe, emisja zanieczyszczeń, testy jezdne, procesy stochastyczne

\section{Introduction}

The pollutant emission from automotive internal combustion (IC) engines is highly susceptible to engine operation states [14], and to both the static engine operation states and the occurrence of dynamic states. For an automotive engine, the state of its operation is mainly determined by the vehicle velocity process. Therefore, the ecological properties of automotive engines in terms of pollutant emission are explored by carrying out empirical research using vehicle driving tests, developed to simulate the conditions of vehicle operation in real road traffic. Such tests have the form of running the engine under test in accordance with predefined time domains of vehicle velocity.

The vehicle driving tests may be formulated in accordance with specific criteria of similarity between the test parameters and the actual conditions of vehicle motion. The first vehicle driving tests were designed in accordance with the criterion of similarity between the characteristics, mostly point-type, of the test conditions and actual vehicle operation conditions, e.g. such as the vehicle velocity process, the similarity of extreme values, average value, variance, or probability density, and for the acceleration process, the similarity of extreme values, and average values of the positive and negative acceleration. This criterion was taken as a basis for the preparation of such tests as for e.g. NEDC (New European Driving Cycle), Japan 10-15 Mode [26, 27], BAC

\section{Wstęp}

Emisja zanieczyszczeń jest bardzo uzależniona od stanów pracy silników spalinowych [14] i to zarówno od stanów statycznych, jak i od występowania stanów dynamicznych. W odniesieniu do silników samochodowych stan ich pracy jest zdeterminowany przede wszystkim procesem prędkości samochodów. $Z$ tego powodu w celu poznania właściwości ekologicznych silników samochodowych ze względu na emisję zanieczyszczeń prowadzi się badania empiryczne w testach jezdnych, opracowanych jako warunki symulujące użytkowanie trakcyjne pojazdów. Testy te stanowią przebiegi prędkości samochodu w dziedzinie czasu.

Testy jezdne można tworzyć z zastosowaniem określonych kryteriów podobieństwa właściwości testów i rzeczywistych warunków ruchu samochodów. Pierwsze testy jezdne były tworzone zgodnie z kryterium podobieństwa charakterystyk, najczęściej punktowych, warunków badań oraz rzeczywistego użytkowania pojazdów, np. podobieństwa dla procesu prędkości jazdy samochodu: wartości ekstremalnych, wartości średniej, wariancji, czy gęstości prawdopodobieństwa, a dla procesu przyspieszenia: wartości ekstremalnych i wartości średniej przyspieszeń dodatniego i ujemnego. Zgodnie z tym kryterium opracowano m.in. testy: NEDC (New European Driving Cycle) i Japan 10-15 Mode [26, 27], BAC (Business Arterial Commuter), WVU 5-Peak (West Virginia University), SRC (Standard Road 
(Business Arterial Commuter), WVU 5-Peak (West Virginia University), SRC (Standard Road Cycle) [27], or Colombia Test [23]. Another method of designing the vehicle driving tests is faithful simulation in time domain. Examples of the tests designed in accordance with this criterion are FTP-75 (Federal Test Procedure), HWFET (Highway Fuel Economy Test), SFTP SC03 (Supplement Federal Test Procedure), or California UC (United Cycle) [27]. Other criteria of similarity, e.g. between spectral characteristics, can also be used $[13,14]$.

Usually, the ecological properties of automotive engines in terms of pollutant emission are assessed based on the results of tests carried out within type-approval procedures. However, the conditions of real vehicle operation may differ greatly from the type-approval conditions. Hence, the characteristics of IC engines, and above all the pollutant emission, may in certain circumstances significantly deviate from those determined in the conditions of type-approval tests, especially in the case of severe traffic difficulties, which frequently occur in the central parts of large urban agglomerations $[3,4]$ or at very heavy engine loads, e.g. during motorway drives [4]. Because of this, researchers also try to determine the characteristics of IC engines in conditions differing from those applied in the type-approval procedures [1-11, 13-25]. In some of the research works, attempts are also made to treat the properties of automotive IC engines as stochastic processes [1, 5, 8-11, 13-15, 17]. Another approach, having been dynamically developed in the recent period, is the examination of pollutant emission in the real conditions of operation of motor vehicles [2, 19-23].

The authors of this paper decided to verify the results of examination of pollutant emission from an automotive IC engine, obtained from selected type-approval tests and from special tests representing the conditions of street congestions and on motorways. For the said verification, results of special tests developed by the authors to simulate the motion of passenger cars in Polish conditions [9] were used.

\section{Tests used to simulate the motion of passenger cars in Polish conditions}

In the article [9], a task was undertaken to develop vehicle driving tests that would represent the typical mode of operation of motor vehicles in Polish conditions. With this goal in mind, a concept was adopted to treat the vehicle velocity processes in characteristic vehicle motion conditions, i.e. in street congestion, urban, extra-urban, and high-speed (motorway and fast road) traffic conditions, as stochastic processes. The tests, treated as realizations of stochastic processes, were designed in compliance with the rule of faithful simulation in time domain. The tests were defined based on the results of testing a Honda Civic passenger car operated on roads of Mazowieckie and Łódzkie Voivodships.

As a result of the investigations carried out, four PIMOT tests were prepared for each vehicle operation mode, with treating them as realizations of stochastic processes of vehicle velocity characterizing the vehicle operation modes in the following conditions:

- street congestions (denoted by “CT”);
Cycle) [27], Colombia Test [23]. Innym sposobem tworzenia testów jezdnych jest wierna symulacja w dziedzinie czasu. Zgodnie z tym kryterium opracowano m.in. testy: FTP-75 (Federal Test Procedure), HWFET (Highway Fuel Economy Test), SFTP SC03 (Supplement Federal Test Procedure), czy California UC (Unified Cycle) [27]. Istnieje również możliwość zastosowania innych kryteriów podobieństwa, np. charakterystyk widmowych [13, 14].

Zazwyczaj do oceny właściwości ekologicznych silników samochodowych ze względu na emisję zanieczyszczeń wykorzystuje się wyniki badań w testach stosowanych w procedurach homologacyjnych. Rzeczywiste warunki użytkowania samochodów mogą jednak znacznie odbiegać od warunków homologacyjnych. W niektórych warunkach właściwości silników spalinowych, przede wszystkim emisja zanieczyszczeń, mogą - w związku z tym - znacznie odbiegać od właściwości w warunkach testów homologacyjnych, szczególnie w sytuacji dużych utrudnień w ruchu, co często występuje w centrach wielkich aglomeracji miejskich [3, 4], albo przy bardzo dużym obciążeniu silnika, np. w czasie jazdy na autostradach [4]. W związku z tym są podejmowane badania właściwości silników spalinowych w warunkach innych niż w procedurach homologacyjnych [1-11, 13-25]. W niektórych pracach są podejmowane próby potraktowania właściwości samochodowych silników spalinowych jako procesów stochastycznych [1, 5, 8-11, 13-15, 17]. Innym rodzajem badań, rozwijanym dynamicznie w ostatnim czasie, są badania emisji zanieczyszczeń w rzeczywistych warunkach użytkowania pojazdów samochodowych [2, 19-23].

Autorzy niniejszego artykułu postanowili zweryfikować wyniki badań emisji z samochodowego silnika spalinowego, uzyskane w wybranych testach homologacyjnych oraz w testach specjalnych, stosowanych do badań w warunkach zatorów ulicznych oraz na autostradach. Do weryfikacji tych wyników wykorzystano wyniki badań w specjalnych testach, opracowanych przez autorów w celu symulacji ruchu samochodów osobowych w warunkach polskich [9].

\section{Testy do symulacji ruchu samochodów osobowych w warunkach polskich}

W publikacji [9] przedstawiono opracowanie testów jezdnych, charakteryzujących sposób użytkowania samochodów w warunkach polskich. Przyjęto koncepcję, aby procesy prędkości w charakterystycznych warunkach ruchu samochodów, tzn. w zatorach ulicznych, w miastach, poza miastami oraz na autostradach i drogach ekspresowych, potraktować jako procesy stochastyczne. Do opracowania testów, stanowiących realizacje procesów stochastycznych, wykorzystano zasadę wiernej symulacji w dziedzinie czasu. Testy wyznaczano na podstawie wyników badań samochodu osobowego Honda Civic, eksploatowanego na drogach województw mazowieckiego i łódzkiego.

W wyniku przeprowadzonych badań opracowano po cztery testy PIMOT, stanowiące realizacje procesów stochastycznych prędkości samochodu, charakteryzujących jego użytkowanie w warunkach:

- zatorów ulicznych - CT,

- w miastach bez zatorów ulicznych - UT, 
- urban traffic without congestions (denoted by “UT");

- extra-urban (rural) traffic (denoted by “RT");

- high-speed traffic (on motorways and fast roads, denoted by "HT").

Four realizations of the vehicle velocity process in the vehicle driving test have been presented in each of the graphs below (Figs 1 to 4 ).

The driving tests developed significantly differ from each other in their properties [7-11]. The average vehicle velocity values in individual realizations of the driving tests were:

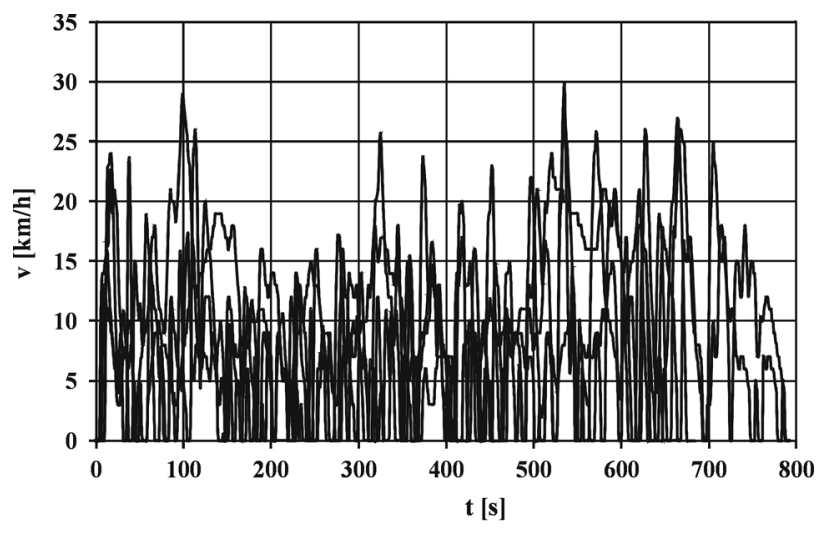

Fig. 1. Realizations of the process of vehicle velocity for test drives in street congestions - CT

Rys. 1. Realizacje procesu prędkości $v$ w testach jazdy $w$ zatorach ulicznych $-C T$

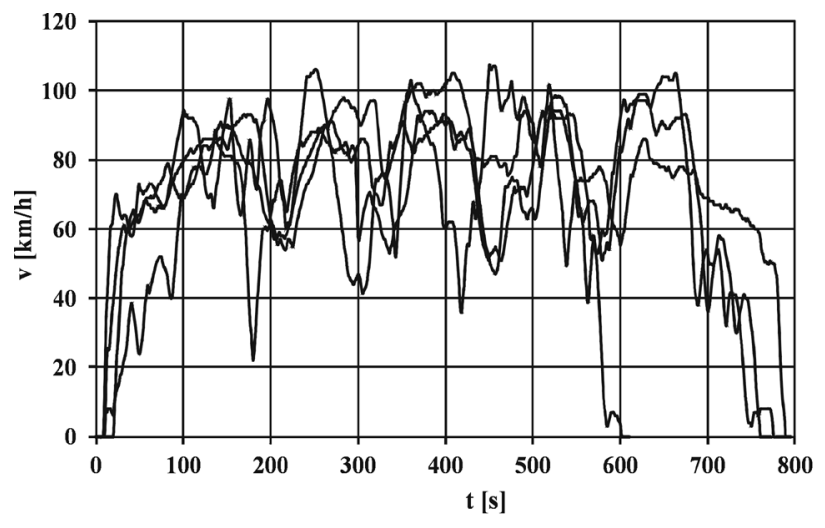

Fig. 3. Realizations of the process of vehicle velocity for test drives in extra-urban (rural) traffic - RT

Rys. 3. Realizacje procesu prędkości $v$ w testach jazdy poza miastami $-R T$

about $8 \mathrm{~km} / \mathrm{h}$ for the test drives in street congestions, about $36 \mathrm{~km} / \mathrm{h}$ for the test drives in urban traffic without congestions, about $76 \mathrm{~m} / \mathrm{h}$ for the test drives in extra-urban (rural) traffic, and about $134 \mathrm{~km} / \mathrm{h}$ for the test drives in high-speed traffic (on motorways and fast roads).

\section{Results of the examination of pollutant emission from a passenger car engine in the driving tests}

The tests were carried out on a Honda Civic EJ9 passenger car (trade name of the car model: Civic 3D 1.4i) with a spark-
- poza miastami - RT,

- na autostradach i drogach ekspresowych - HT.

Na rysunkach 1-4 przedstawiono po cztery realizacje procesu prędkości w opracowanych testach jezdnych.

Opracowane testy jezdne znacznie różnią się właściwościami [7-11]. Prędkość średnia w poszczególnych realizacjach testów wynosi dla: jazdy w zatorach ulicznych około $8 \mathrm{~km} / \mathrm{h}$, w miastach bez zatorów ulicznych - około 36 $\mathrm{km} / \mathrm{h}$, poza miastami - około $76 \mathrm{~km} / \mathrm{h}$ oraz na autostradach i drogach ekspresowych - około $134 \mathrm{~km} / \mathrm{h}$.

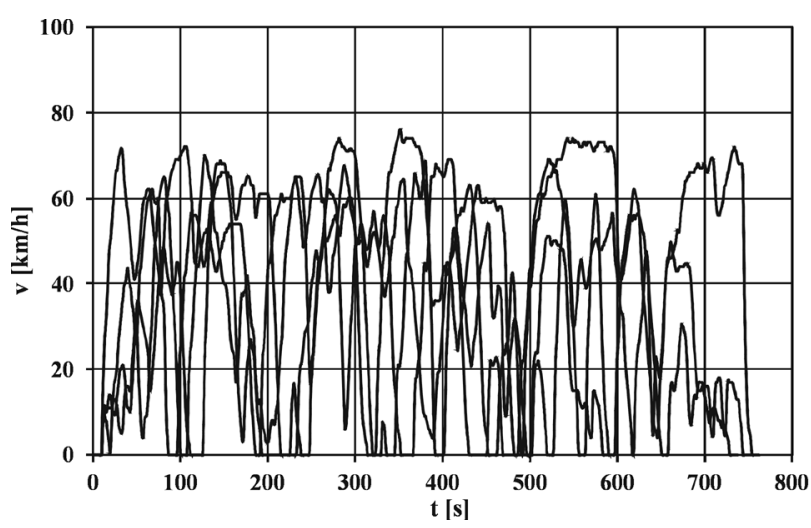

Fig. 2. Realizations of the process of vehicle velocity for test drives in urban traffic without congestions - UT

Rys. 2. Realizacje procesu prędkości $v$ w testach jazdy $w$ miastach bez zatorów ulicznych - UT

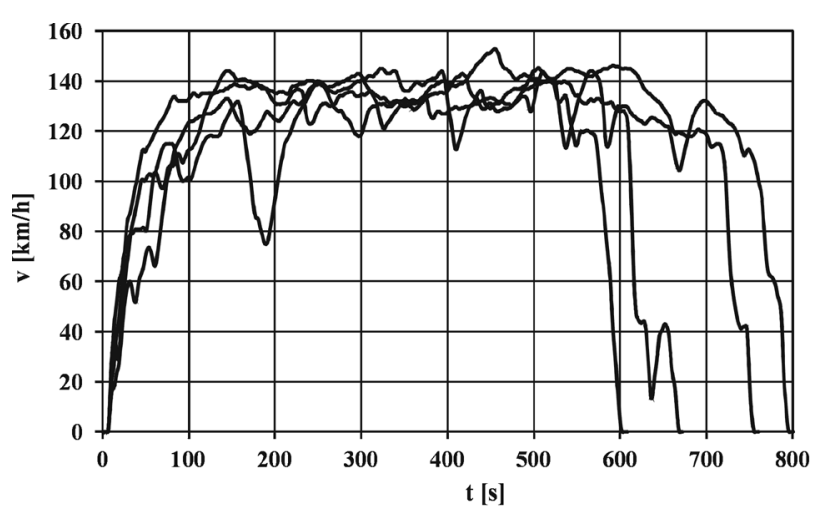

Fig. 4. Realizations of the process of vehicle velocity for test drives in high-speed traffic (on motorways and fast roads) - HT

Rys. 4. Realizacje procesu prędkości $v$ w testach jazdy na autostradach $i$ drogach ekspresowych $-H T$

\section{Wyniki badań emisji zanieczyszczeń z silnika samochodu osobowego w testach jezdnych}

Obiektem badań był samochód osobowy Honda Civic EJ9 (nazwa handlowa Civic 3D 1.4i) z silnikiem o zapłonie iskrowym o objętości skokowej $1396 \mathrm{~cm}^{3}$, spełniający wymagania emisji zanieczyszczeń na poziomie Euro 3.

Badania samochodu prowadzono w stanie silnika spalinowego nagrzanego do ustabilizowanej temperatury. Badania przeprowadzono na stanowisku hamowni podwoziowej Schenk Komeg EMDY 48. Aparatura zastosowana do badań 
ignition engine and a displacement of $1396 \mathrm{~cm}^{3}$, meeting the requirements of the Euro 3 exhaust emission standard.

The car was tested with its engine having been heated to a stable temperature. The Honda Civic car was tested on a vehicle chassis dynamometer Schenk Komeg EMDY 48. The research equipment used for the tests meets the requirements of Directive 1999/96/EC of the European Parliament and of the Council. To examine the pollutant emission, an exhaust gas analysing test stand was used, which incorporated Horiba Mexa 7200 system provided with Horiba analysers to measure the concentrations of carbon monoxide (AIA-721A), hydrocarbons (FIA-725A), nitrogen oxides (CLA-755A), carbon dioxide (AIA-722), and oxygen (MPA-720).

The tests were carried out in compliance with typeapproval procedures UDC (Urban Driving Cycle), EUDC (Extra Urban Driving Cycle), NEDC, FTP-75, Japan 10-15 Mode, and HWFET, special test procedures "Stop-and-Go" and "Autobahn" [4], and the PIMOT test procedure. The car tests according to the PIMOT procedure were carried out five times, with four realizations for each test.

Figures 5-8 show the average value and the standard deviation of specific distance pollutant emission in the UDC, EUDC, NEDC, FTP-75, Japan 10-15 Mode, and HWFET type-approval tests and in the "Autobahn" and "Stop-andGo" special tests.

The average value and the standard deviation of the emission of pollutants determined for the whole sets of realizations of the PIMOT driving tests have been presented in Figs 9-12.

To assess the curves representing the relations between emission and average vehicle velocity in the type-approval and special driving tests and in the PIMOT driving tests, the mutually corresponding curves have been compared with each other in Figs 13-16.

The curves plotted as characteristics of specific distance emission of pollutants are consistent with the relations de-

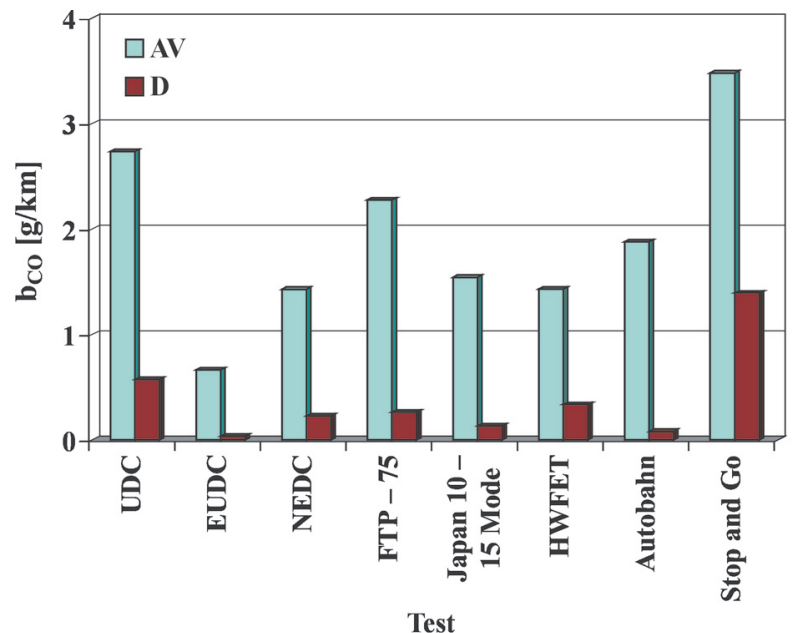

Fig. 5. Specific distance emission of carbon monoxide in the type-approval and special driving tests: AV - average value, D - standard deviation Rys. 5. Emisja drogowa tlenku węgla w testach homologacyjnych i specjalnych: $A V$-wartość średnia, D-odchylenie standardowe spełniała wymagania dyrektywy 1999/96/WE Parlamentu Europejskiego i Rady. Do badań emisji zanieczyszczeń wykorzystano stanowisko do analizy spalin, w którego skład wchodzi system Horiba Mexa 7200 wyposażony w analizatory Horiba do pomiarów stężeń: tlenku węgla (AIA-721A), węglowodorów (FIA-725A), tlenków azotu (CLA-755A), dwutlenku węgla (AIA-722) i tlenu (MPA-720).

Jako testy homologacyjne przyjęto do badań: UDC (Urban Driving Cycle), EUDC (Extra Urban Driving Cycle), NEDC, FTP-75, Japan 10-15 Mode i HWFET, a jako testy specjalne: Stop and Go i Autobahn [4]. Badania w testach PIMOT odbywały się w czterech realizacjach dla każdego testu. Badania samochodu w każdym z testów wykonywano pięciokrotnie.

$\mathrm{Na}$ rysunkach 5-8 przedstawiono wartość średnią i odchylenie standardowe emisji drogowej zanieczyszczeń w testach homologacyjnych: UDC, EUDC, NEDC, FTP-75, Japan 10-15 Mode i HWFET oraz w testach specjalnych: Autobahn i Stop and Go.

Na rysunkach 9-12 przedstawiono wartość średnią i odchylenie standardowe emisji drogowej zanieczyszczeń w zbiorach testów PIMOT.

W celu oceny charakterystyk zależności emisji drogowej zanieczyszczeń od prędkości średniej w testach homologacyjnych i specjalnych oraz w testach PIMOT przedstawiono je na rysunkach 13-16.

Wyznaczone charakterystyki emisji drogowej zanieczyszczeń są zgodne z zależnościami wyznaczanymi na podstawie dostępnych wyników badań, np. na podstawie baz danych, zawartych w specjalistycznych oprogramowaniach, takich jak INFRAS [18], COPERT [16] oraz w pracach $[11,12,14]$. Ogólnie są spełnione pewne prawidłowości. Dla dużych utrudnień ruchu, dla których jest mała prędkość średnia, jest duża emisja drogowa zanieczyszczeń, szczególnie węglowodorów i tlenku węgla. Również jest znamienne zwiększanie się dla dużej prędkości średniej, odpowiadającej dużemu obciążeniu silników, emisji dro-

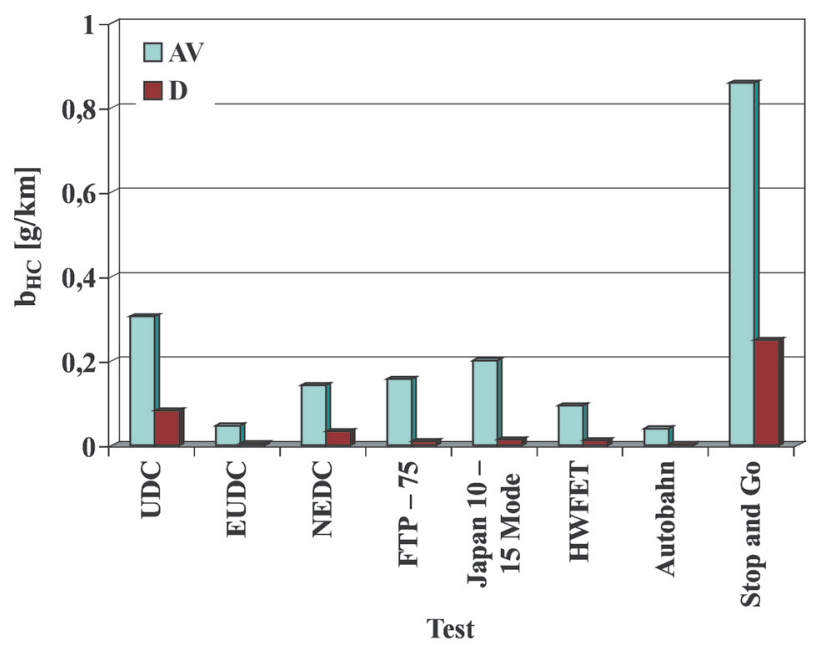

Fig. 6. Specific distance emission of hydrocarbons in the type-approval and special driving tests: AV - average value, D - standard deviation Rys. 6. Emisja drogowa węglowodorów w testach homologacyjnych i specjalnych: $A V$-wartość średnia, D-odchylenie standardowe 


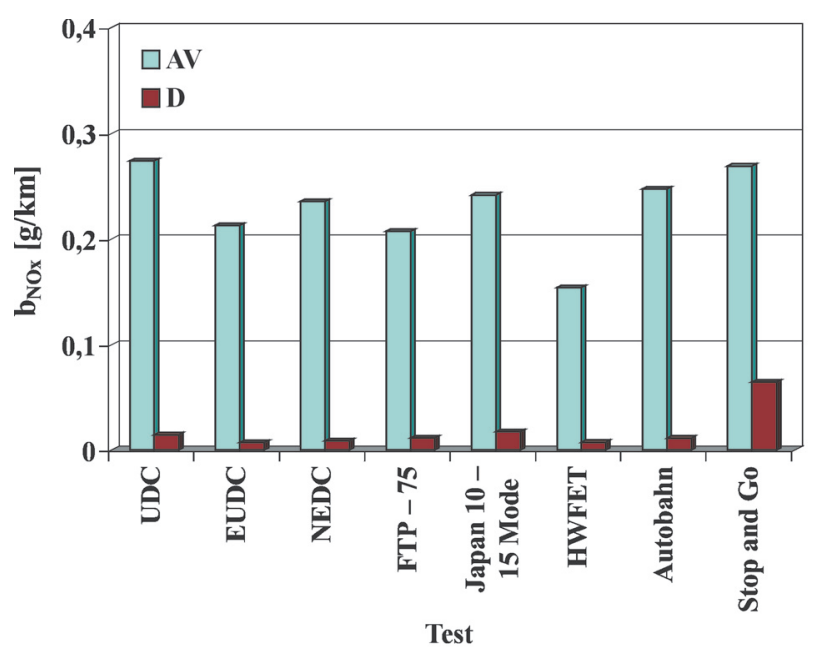

Fig. 7. Specific distance emission of nitrogen oxides in the type-approval and special driving tests: $\mathrm{AV}$ - average value, $\mathrm{D}$ - standard deviation

Rys. 7. Emisja drogowa tlenków azotu w testach homologacyjnych i specjalnych: $A V$ - wartość średnia, $D$ - odchylenie standardowe

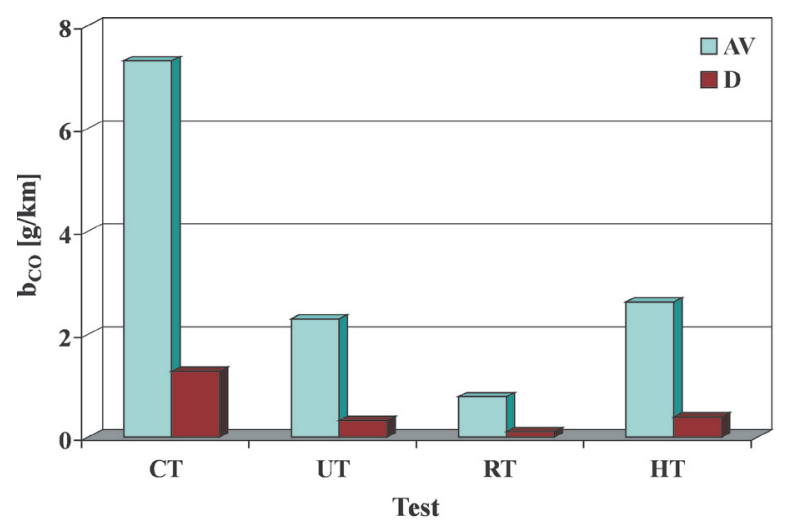

Fig. 9. Specific distance emission of carbon monoxide in the PIMOT driving tests: $\mathrm{AV}$ - average value, $\mathrm{D}$ - standard deviation

Rys. 9. Emisja drogowa tlenku węgla w testach PIMOT: AV-wartość średnia, D-odchylenie standardowe

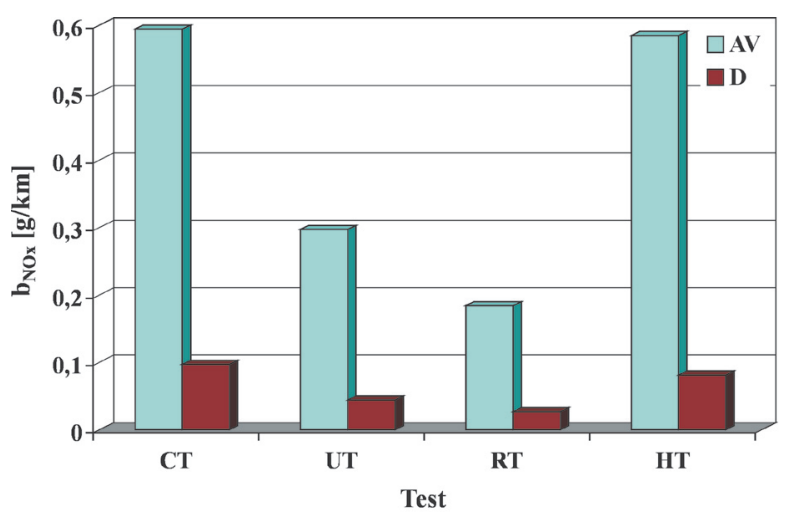

Fig. 11. Specific distance emission of nitrogen oxides in the PIMOT driving tests: $\mathrm{AV}$ - average value, $\mathrm{D}$ - standard deviation

Rys. 11. Emisja drogowa tlenków azotu w testach PIMOT: AV-wartość średnia, D-odchylenie standardowe

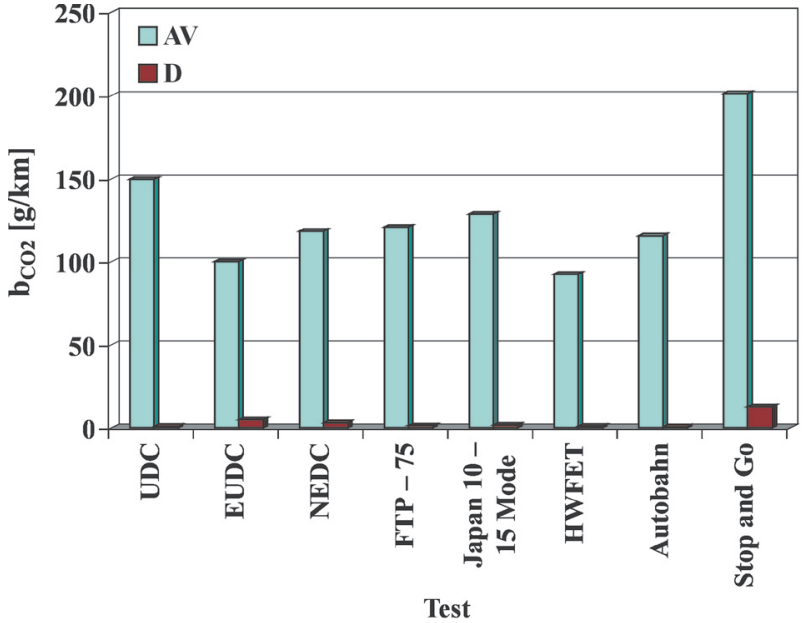

Fig. 8. Specific distance emission of carbon dioxide in the type-approval and special driving tests: $\mathrm{AV}$ - average value, $\mathrm{D}$ - standard deviation Rys. 8. Emisja drogowa dwutlenku wegla w testach homologacyjnych i specjalnych: $A V$ - wartość średnia, D-odchylenie standardowe

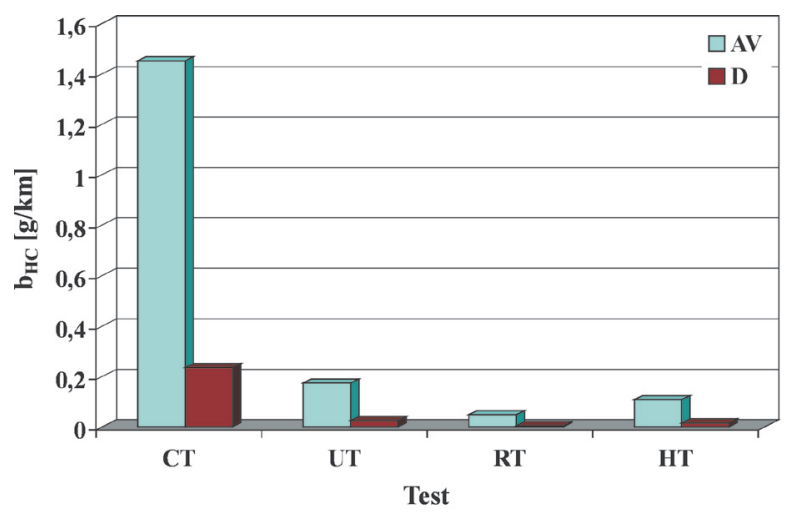

Fig. 10. Specific distance emission of hydrocarbons in the PIMOT driving tests: $\mathrm{AV}$ - average value, $\mathrm{D}$ - standard deviation

Rys. 10. Emisja drogowa węglowodorów w testach PIMOT: $A V$-wartość średnia, D-odchylenie standardowe

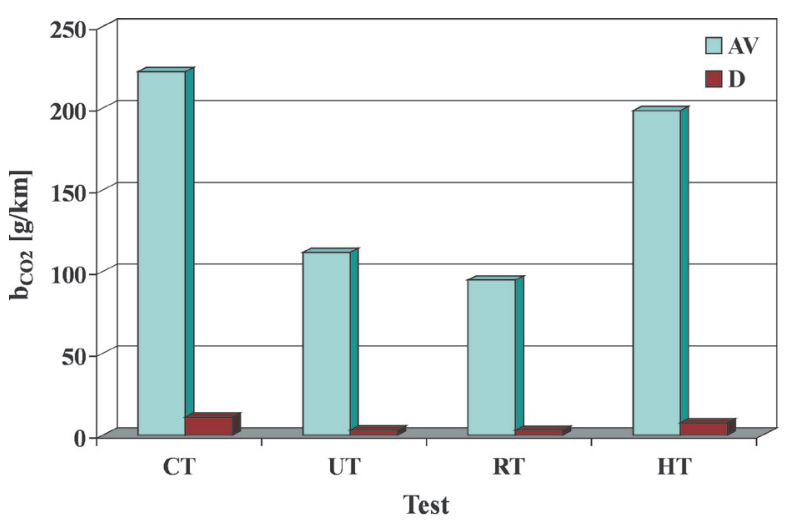

Fig. 12. Specific distance emission of carbon dioxide in the PIMOT driving tests: $\mathrm{AV}$ - average value, $\mathrm{D}$ - standard deviation

Rys. 12. Emisja drogowa dwutlenku wegla w testach PIMOT: $A V$ - wartość średnia, D-odchylenie standardowe 
termined from the available research results, e.g. from the databases incorporated in specialist computer programs such as INFRAS [18] or COPERT [16] or given in publications $[11,12,14]$. In general, some regularities can be observed in these characteristics. In the case of severe traffic difficulties,

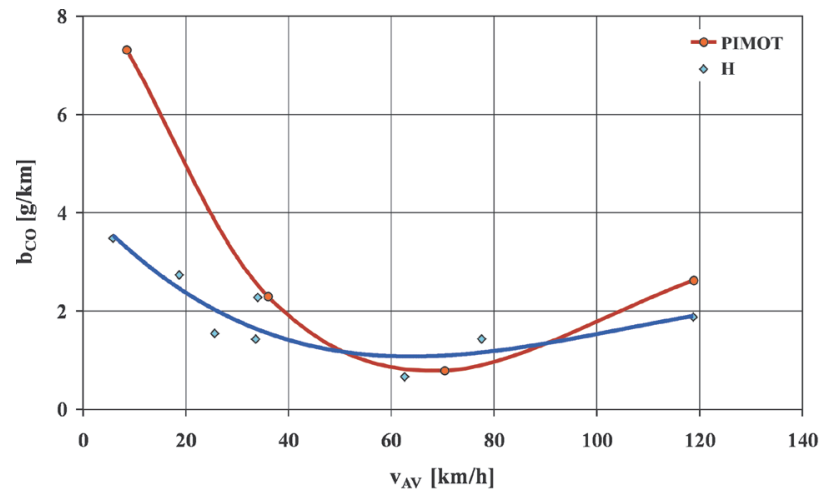

Fig. 13. Specific distance emission of carbon monoxide vs. average vehicle velocity curves, plotted for the type-approval and special driving tests $(\mathrm{H})$ and for the PIMOT driving tests

Rys. 13. Porównanie zależności emisji drogowej tlenku węgla w testach homologacyjnych i specjalnych - H oraz w testach PIMOT od prędkości średniej

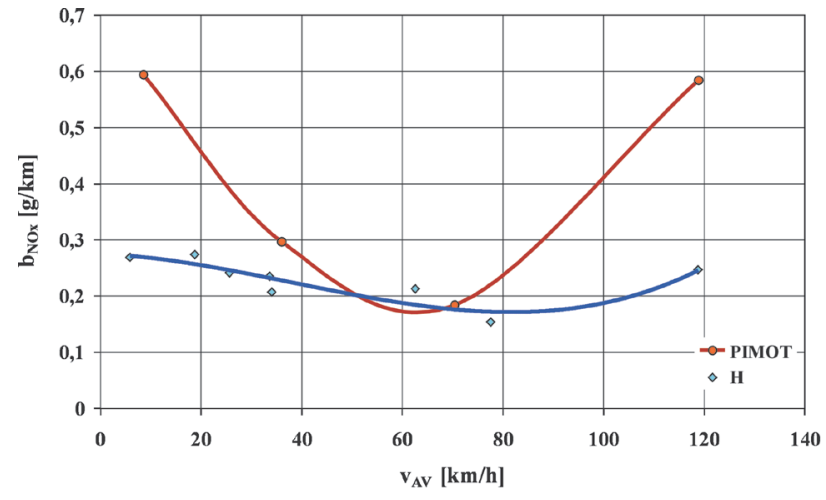

Fig. 15. Specific distance emission of nitrogen oxides vs. average vehicle velocity curves, plotted for the type-approval and special driving tests $(\mathrm{H})$ and for the PIMOT driving tests

Rys. 15. Porównanie zależności emisji drogowej tlenków azotu w testach homologacyjnych i specjalnych - H oraz w testach PIMOT od prędkości średniej

where the average vehicle velocity is low, the emission is high, especially the emission of hydrocarbons and carbon monoxide. It is also symptomatic that at high average velocity, corresponding to heavy engine loads, a growth is observed in the emission of nitrogen oxides, carbon dioxide, and, to a smaller extent, carbon monoxide.

Noteworthy is also the fact that: for the characteristic curves determined from the PIMOT tests, the differences between the emission values for low and high average vehicle velocity and for medium velocity are bigger than those observed in the characteristic curves plotted using the results of type-approval and special tests. This is even more interesting when taking into account that for some vehicle motion modes gowej tlenków azotu i dwutlenku węgla i - w mniejszym stopniu - tlenku węgla

Jest znamienne, że dla charakterystyk wyznaczonych na podstawie testów PIMOT różnice między wartościami dla małych i dużych prędkości średnich samochodu oraz dla

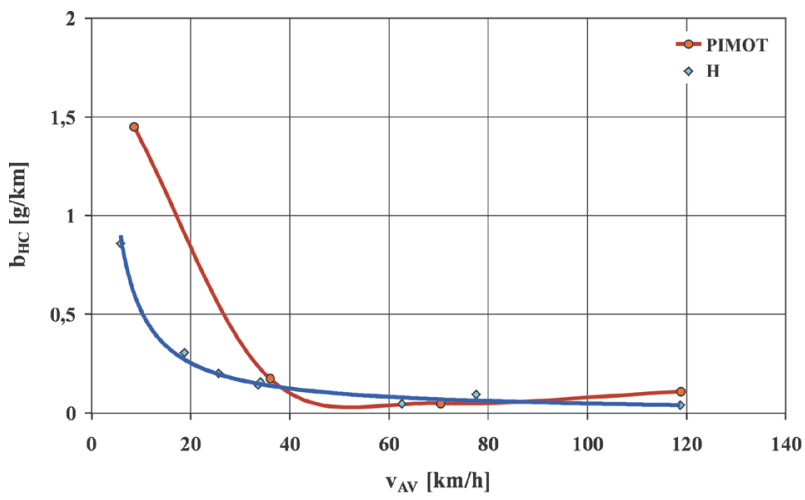

Fig. 14. Specific distance emission of hydrocarbons vs. average vehicle velocity curves, plotted for the type-approval and special driving tests $(\mathrm{H})$ and for the PIMOT driving tests

Rys. 14. Porównanie zależności emisji drogowej węglowodorów $w$ testach homologacyjnych $i$ specjalnych - H oraz $w$ testach PIMOT od prędkości średniej

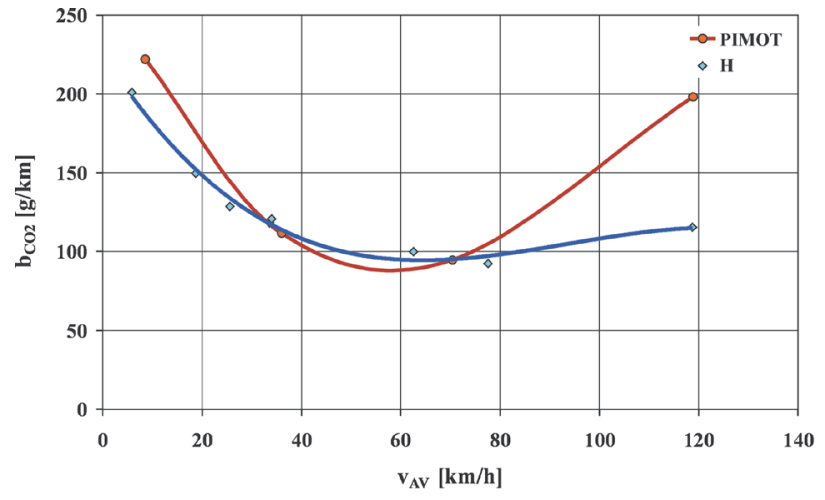

Fig. 16. Specific distance emission of carbon dioxide vs. average vehicle velocity curves, plotted for the type-approval and special driving tests $(\mathrm{H})$ and for the PIMOT driving tests

Rys. 16. Porównanie zależności emisji drogowej dwutlenku węgla $w$ testach homologacyjnych $i$ specjalnych - H oraz $w$ testach PIMOT od prędkości średniej

prędkości umiarkowanych są większe niż dla charakterystyk wyznaczonych na podstawie testów homologacyjnych i specjalnych. Jest to tym bardziej interesujące, że niektóre modele ruchu spośród testów homologacyjnych i specjalnych oraz testów PIMOT mają podobną prędkość średnią. Potwierdza to znany z badań emisji zanieczyszczeń z silników samochodowych fakt, że procesy emisji zanieczyszczeń są silnie zależne od przebiegów wielkości charakteryzujących stan pracy silnika, zdeterminowany przede wszystkim procesem prędkości pojazdu $[4,13,14,18]$. Potwierdza to także celowość traktowania warunków ruchu pojazdów do celów oceny emisji zanieczyszczeń z silników samochodowych jako procesów stochastycznych. 
among those used in the type-approval and special tests and in the PIMOT tests, the average vehicle velocity takes similar values. This confirms the fact, known from other research works on the pollutant emission from automotive engines, that the pollutant emission processes are strongly dependent on changes of the quantities that characterize the engine operation state, determined above all by the vehicle velocity process $[4,13,14,18]$. Thus, it should be considered useful to treat vehicle motion conditions as stochastic processes when they are analysed for the purposes of evaluation of pollutant emission from automotive engines.

Additionally, relations between the specific distance pollutant emission in type-approval, special, and PIMOT tests and the average vehicle velocity were determined (Figs 17-20). The sets of points were approximated by a polynomial function of the $3 \mathrm{rd}$ or 4 th degree or by a power function (for hydrocarbons).

In the graphs above, differences, significant in some cases, between the pollutant emission values can be clearly seen in the sets of measurement results used; simultaneously, the curves that approximate the sets of test results, which

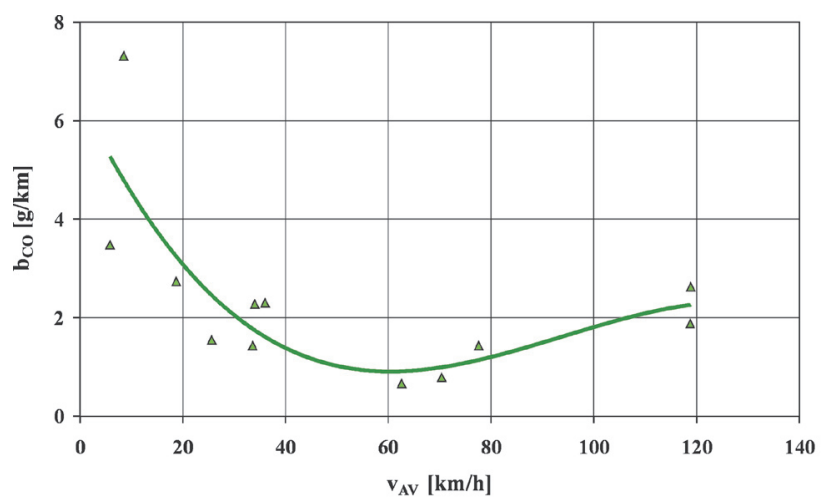

Fig. 17. Relation between the specific distance emission of carbon monoxide and the average vehicle velocity in type-approval, special, and PIMOT tests

Rys. 17. Zależność emisji drogowej tlenku węgla w testach homologacyjnych i specjalnych oraz $w$ testach PIMOT od prędkości średniej

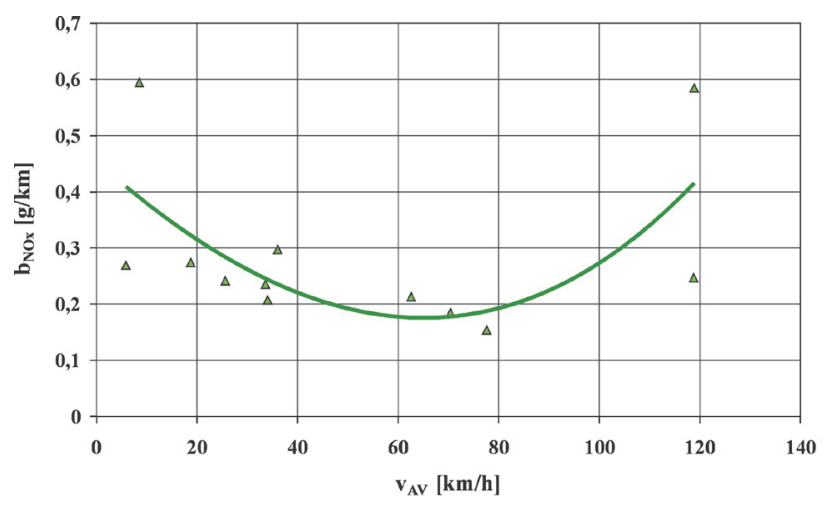

Fig. 19. Relation between the specific distance emission of nitrogen oxides and the average vehicle velocity in type-approval, special, and PIMOT tests

Rys. 19. Zależność emisji drogowej tlenków azotu w testach homologacyjnych i specjalnych oraz w testach PIMOT od prędkości średniej
Dodatkowo wyznaczono zależności emisji drogowej zanieczyszczeń w testach homologacyjnych i specjalnych oraz w testach PIMOT od prędkości średniej - rysunki 17-20. Zbiory punktów aproksymowano funkcją wielomianową o stopniach 3 lub 4, albo funkcją potęgową (w odniesieniu do węglowodorów).

$\mathrm{Na}$ wykresach tych są wyraźnie widoczne znaczne niekiedy różnice wartości emisji drogowej zanieczyszczeń dla wykorzystywanych zbiorów wyników pomiarów, jednocześnie linie aproksymujące zbiory wyników badań, będące sumami zbiorów, pochodzących $\mathrm{z}$ badań $\mathrm{w}$ testach homologacyjnych i specjalnych oraz w testach PIMOT, wykazują tendencje zbieżne $\mathrm{z}$ charakterystykami wyznaczanymi dla poszczególnych pojazdów $[12,16,18]$ oraz dla kategorii pojazdów $[12,16,18]$.

\section{Podsumowanie}

Poziom nieokreśloności stanów pracy silników spalinowych użytkowanych w pojazdach samochodowych uzasadnia traktowanie warunków pracy tych silników jako przypadkowych. W związku z tym zaproponowano wyzna-

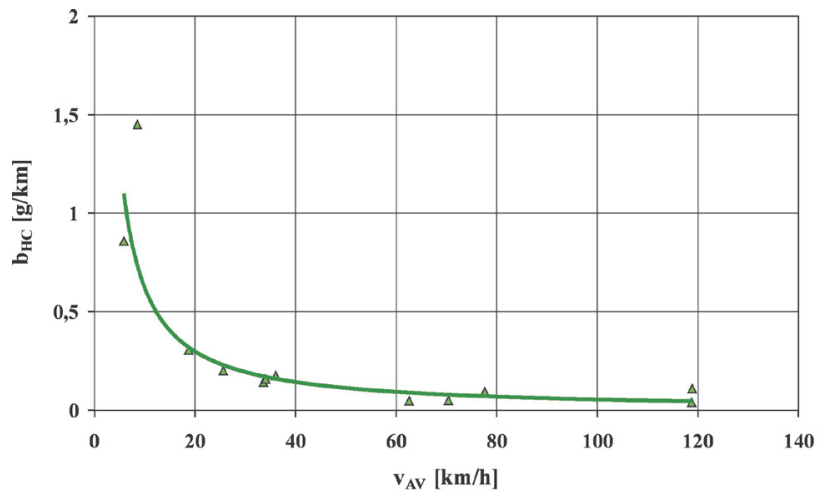

Fig. 18. Relation between the specific distance emission of hydrocarbons and the average vehicle velocity in type-approval, special, and PIMOT tests

Rys. 18. Zależność emisji drogowej węglowodorów w testach homologacyjnych i specjalnych oraz $w$ testach PIMOT od prędkości średniej

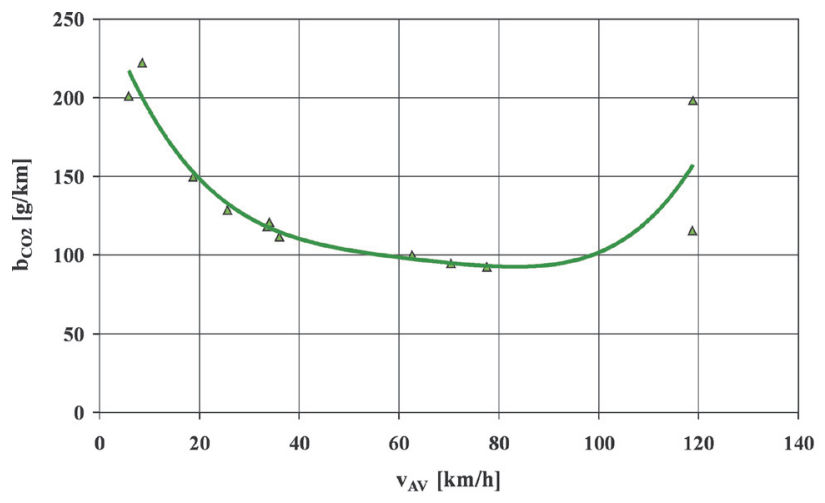

Fig. 20. Relation between the specific distance emission of carbon dioxide and the average vehicle velocity in type-approval, special, and PIMOT tests

Rys. 20. Zależność emisji drogowej dwutlenku węgla w testach homologacyjnych i specjalnych oraz w testach PIMOT od prędkości średniej 
are sums of the sets derived from the tests carried out to the type-approval, special, and PIMOT test procedures, show trends coinciding with the characteristic curves determined for individual vehicles $[12,16,18]$ and vehicle categories $[12,16,18]$.

\section{Conclusions}

The level of indeterminacy of the states of operation of IC engines used in motor vehicles provides grounds for treating the conditions of operation of such engines as varying on a random basis. Therefore, a proposal was made to develop driving tests that would represent the conditions of motion of motor vehicles as realizations of stochastic processes. The tests of this type, named PIMOT tests, were designed in accordance with the criterion of faithful simulation in time domain, based on results of empirical determination of the velocity of a passenger car. To simulate the vehicle motion, models representing the vehicle operation modes in the conditions of street congestions, urban traffic, extra-urban traffic, and high-speed traffic on motorways and fast roads were adopted.

The pollutant emission was examined on a chassis dynamometer in PIMOT tests, type-approval tests (UDC, EUDC, NEDC, HWFET, and Japan 10-15 Mode), and special tests simulating the conditions of vehicle drive in street congestions ("Stop-and-Go") and on motorways (“Autobahn").

The research results revealed high dependence of the pollutant emission from an IC engine on the engine operation conditions. It is important to note the fact that even in tests with similar values of the average vehicle velocity, significant differences occur in the emission of individual pollutants. This confirms the usefulness of treating the conditions of operation of automotive IC engines as stochastic processes.

For both the PIMOT and other test types, the characteristic curves plotted as representing the relation between pollutant emission and average vehicle velocity show regularity and consistency with the current state of knowledge. However, there are differences between the curves being compared. This confirms high dependency of the pollutant emission from IC engines on both the static and dynamic states of engine operation. czanie testów jezdnych, charakteryzujących warunki ruchu pojazdów samochodowych, jako realizację procesów stochastycznych. Testy te, nazwane testami PIMOT, wyznaczono zgodnie $\mathrm{z}$ kryterium wiernej symulacji $\mathrm{w}$ dziedzinie czasu na podstawie wyników badań empirycznych prędkości samochodu osobowego. Przyjęto modele ruchu samochodów w warunkach: zatorów ulicznych, w miastach, poza miastami oraz na autostradach i drogach ekspresowych.

Badania emisji zanieczyszczeń na hamowni podwoziowej przeprowadzono w testach PIMOT oraz w testach homologacyjnych (UDC, EUDC, NEDC, HWFET i Japan 10-15 Mode) i specjalnych, symulujących jazdę w zatorach ulicznych - Stop and Go i na autostradach - Autobahn.

Wyniki badań wykazały znaczną wrażliwość emisji zanieczyszczeń na warunki pracy silnika spalinowego. Jest znamienne, że nawet dla testów o zbliżonej wartości średniej prędkości bywają znaczne różnice wartości średniej emisji drogowej zanieczyszczeń. Potwierdza to celowość traktowania warunków pracy samochodowych silników spalinowych jako procesów stochastycznych.

Wyznaczone charakterystyki emisji zanieczyszczeń w zależności od wartości średniej wykazują dla obydwu rodzajów testów regularność i zgodność ze stanem wiedzy, jednocześnie jednak występują między porównywanymi charakterystykami różnice. Potwierdza to znaczną wrażliwość emisji zanieczyszczeń zarówno na statyczne, jak i dynamiczne stany pracy silników.

This paper was based on results of tests carried out as a part of research project No. N N509 556440 entitled "Sensitivity of pollutant emission and fuel consumption to the conditions of use of a spark-ignition engine for mobile applications", sponsored by the National Science Centre.

Artykuł opracowano na podstawie wyników badań realizowanych w pracy N N509 556440 ,, Wrażliwość emisji zanieczyszczeń i zużycia paliwa na warunki użytkowania trakcyjnego silnika o zapłonie iskrowym", finansowanej ze środków Narodowego Centrum Nauki.

\section{Bibliography/Literatura}

[1] Abou Zeid M., Chabini I., Nam E.K., Cappiello A. Probabilistic modeling of acceleration in traffic networks as a function of speed and road type. Proceedings of the IEEE 5th International Conference on Intelligent Transportation Systems, Singapore, September 2002, 472-478.

[2] Arregle J., Bermudez V., Serrano J.R., Fuentes E. Procedure for engine transient cycle emissions testing in real time. Experimental Thermal And Fluid Science 2006, 30 (5), 485-496.

[3] Beevers S.D., Carslaw D.C. The impact of congestion charging on vehicle emissions in London. Atmospheric Environment 2005, 39 (1), 1-5.

[4] BUWAL, INFRAS AG. Luftschadstoffemissionen des Strassenverkehrs 1950-2010. BUWAL-Bericht Nr. 255, 1995.

[5] Cappiello A., Chabini I., Nam E. K., Lue A., Abou Zeid M. A statistical model of vehicle emissions and fuel consumption.
Proceedings of the IEEE 5th International Conference on Intelligent Transportation Systems, Singapore, September 2002, 801-809.

[6] Chin A.T.H. Containing air pollution and traffic congestion: transport policy and the environment in Singapore. Atmospheric Environment 1996, 30 (5), 787-801.

[7] Chłopek Z., Biedrzycki J., Lasocki J., Wójcik P. Emisja zanieczyszczeń z silnika samochodu w testach jezdnych symulujących rzeczywiste użytkowanie trakcyjne. Zeszyty Naukowe Instytutu Pojazdów 2013, 92 (1), 65-74.

[8] Chłopek Z., Biedrzycki J., Lasocki J., Wójcik P. Investigation of pollutant emissions from a motor vehicle engine in tests simulating real vehicle use in road traffic conditions. Combustion Engines 2013, 154 (3), 202-207. 
[9] Chłopek Z., Biedrzycki J., Lasocki J., Wójcik P. Report of research project No. N N509 556440 "Sensitivity of pollutant emission and fuel consumption to the conditions of use of a spark-ignition engine for mobile applications". Warszawa 2013 (not published, in Polish).

[10] Chłopek Z., Biedrzycki J., Lasocki J., Wójcik P. Investigation of the motion of motor vehicles in Polish conditions. The Archives of Automotive Engineering - Archiwum Motoryzacji 2013, 60 (2), 3-20.

[11] Chłopek Z., Laskowski P. Pollutant emission characteristics determined using the Monte Carlo Method. Eksploatacja i Niezawodność - Maintenance and Reliability 2009, 42 (2), 42-51.

[12] Chłopek Z., Zimakowska M. Charakterystyki emisji zanieczyszczeń z samochodowych silników spalinowych (Characteristics of pollutant emission (from) vehicle internal combustion engines). A chapter in the monograph "Współczesne problemy inżynierii i ochrony środowiska (Present-day problems of environmental engineering and protection)". Prace Naukowe Politechniki Warszawskiej - Inżynieria Środowiska, Oficyna Wydawnicza Politechniki Warszawskiej (Publishing House of the Warsaw University of Technology), Warszawa 2009, 55, 53-66.

[13] Chłopek Z. Metody badań właściwości silników spalinowych w warunkach przypadkowych modelujących użytkowanie (Methods of examining the properties of internal combustion engines in random conditions modelling the real engine operation). Archiwum Motoryzacji 2001, 4, 187-210.

[14] Chłopek Z. Modelowanie procesów emisji spalin w warunkach eksploatacji trakcyjnej silników spalinowych (Modelling of exhaust emission processes in the conditions of operation of combustion engines in mobile applications). Prace Naukowe Politechniki Warszawskiej - Mechanika, Oficyna Wydawnicza Politechniki Warszawskiej (Publishing House of the Warsaw University of Technology), Warszawa, 173/1999.

[15] Chłopek Z. The research of the probabilistic characteristics of exhaust emissions from vehicle engines. Combustion Engines - Silniki Spalinowe 2011, 144 (1), 49-56.

[16] COPERT IV - Methodology and Emission Factors. European Environment Agency. European Topic Center on Air Emission, 2000.

[17] Frey H.C., Zheng J. Probabilistic analysis of driving cycle-based highway vehicle emission factors. Environmental Science \& Technology 2002, 36 (23), 5184-5191.

Prof. Zdzisław Chłopek, DSc., DEng. - professor at the Faculty of Automotive and Construction Machinery Engineering at Warsaw University of Technology.

Prof. dr hab. inż. Zdzistaw Chtopek- profesor na Wydziale Samochodów i Maszyn Roboczych Politechniki Warszawskiej.

e-mail: zchlopek@simr.pw.edu.pl

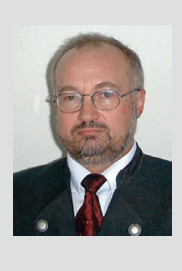

Jakub Lasocki, DEng. - doctor at the Faculty of Automotive and Construction Machinery Engineering at Warsaw University of Technology.

Dr inż. Jakub Lasocki - adiunkt na Wydziale Samochodów i Maszyn Roboczych Politechniki Warszawskiej. e-mail: j.lasocki@simr.pw.edu.pl

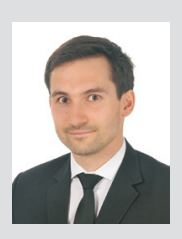

[18] INFRAS AG. Handbuch für Emissionsfaktoren des Strassenverkehrs. Version 3.1. Bern 2010.

[19] Merkisz J., Gis W. Exhaust emission from vehicles under real conditions. Proceedings of the Ninth Asia-Pacific International Symposium on Combustion and Energy Utilization: APISCEU. Beijing, 02-06 November 2008.

[20] Merkisz J., Pielecha J., Gis W. Comparison of vehicle emission factors in NEDC cycle and road test. Proceedings of the Ninth Asia-Pacific International Symposium on Combustion and Energy Utilization: APISCEU. Beijing, 02-06 November 2008.

[21] Romaniszyn K., Nowak A. Analiza wpływu parametrów ruchu pojazdu na zużycie paliwa i emisję zanieczyszczeń przy przejeździe przez Bielsko-Białą (An influence of car motion parameters on fuel consumption and the emission of pollutants). Zeszyty Naukowe OBRSM BOSMAL 2004, 23 (1), 43-49.

[22] Romaniszyn K., Nowak A. Wpływ parametrów ruchu pojazdu na zużycie paliwa i emisję zanieczyszczeń przy przejeździe przez Bielsko-Białą (Influence of car motion parameters on fuel consumption and pollutant emissions during a test drive through Bielsko-Biała). Zeszyty Naukowe - Inżynieria Włókiennicza i Ochrona Środowiska, University of Bielsko-Biała, 2004, Series No. 5: Konferencje, 14, 176-182.

[23] Rostkowski J., Brady J., Torres J. Exhaust emissions testing of fifteen buses in Santafe de Bogotá, D.C. Operating with 1000 and 3000 ppm sulphur diesel. Technical report. Environment Canada, Environmental Technology Centre, Emissions Research Measurement Division and Empresa Colombiana de Petróleos and Instituto Colombiano del Petroleo ECOPETROL. Ottawa 2000.

[24] Sturm P.J. Boulter P., Haan P., Joumard R., Hausberger S., Hickman J., Keller M., Niederle W., Ntziachristos L., Reiter C., Samaras Z., Schinagl G., Schweizer T., Pischinger R. Instantaneous emission data and their use in estimating passenger car emissions. MEET project: Methodologies for estimating air pollutant emissions from transport. Final report COST 319 A2. Technical University of Graz. Graz, Austria 1998.

[25] Wang J., Storey J., Domingo N., Huff S., Thomas J., West B. Studies of diesel engine particle emissions during transient operations using an engine exhaust particle size. Aerosol Science and Technology 2006, 40 (11), 1002-1015.

[26] Worldwide emission standards. Passenger cars and light duty vehicles. Delphi. Innovation for the real world. 2012/2013.

[27] www.dieselnet.com.

Jacek Biedrzycki, MEng. - head of Laboratory of Engines and Chassis in the Automotive Industry Institute in Warsaw.

Mgr inż. Jacek Biedrzycki - kierownik Pracowni Badań Silników i Podwozi w Przemystowym Instytucie Motoryzacji w Warszawie.

e-mail: j.biedrzycki@pimot.eu

Piotr Wójcik, MEng. - scientific and technical specialist in the Automotive Industry Institute in Warsaw.

Mgr inż. Piotr Wójcik - specjalista badawczo-techniczny w Przemystowym Instytucie Motoryzacji $w$ Warszawie.

e-mail:p.wojcik@pimot.eu

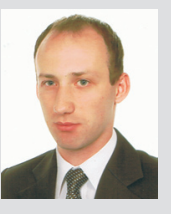

